\title{
Male gametophyte development steps in Pistacia vera $\mathrm{L}$.
}

\author{
ELAHE SADEGHIRAD ${ }^{1}$, AHMAD MAJD ${ }^{2, \bullet}$, ALIREZA IRANBAKHSH ${ }^{1}$, AMANOLLAH JAVANSHAH $^{3}$ \\ ${ }^{1}$ Department of Biology, Faculty of Sciences, Science and Research Branch, Islamic Azad University. Hesarak, Tehran, Iran \\ ${ }^{2}$ Department of Biology, Faculty of Sciences, North Tehran Branch, Islamic Azad University, South Makran Street, Tehran, Iran. "email: \\ majda.iautnb@gmail.com \\ ${ }^{3}$ Pistachio Research Center, Rafsanjan University of Medical Sciences, Rafsanjan, Kerman, Iran
}

Manuscript received: 7 April 2018. Revision accepted: 3 August 2018.

\begin{abstract}
Sadeghirad E, Majd A, Iranbakhsh A, Javanshah A. 2018. Male gametophyte development steps in Pistacia vera L. Nusantara Bioscience 10: 151-158. Salinity affects the growth and development of plant. It also affects the development steps of male gametophyte in pistachio plant. Pistachio (Pistachio vera) is a member of family Anacardiaceae and order Sapindales. To study the effects of salinity on those steps, an experiment was performed in two locations in Golshan Anar with commensurate circumstances, namely: a control area (A) which was well-irrigated with fresh water, and the other area (B) which was well-irrigated with salty water added with $\mathrm{NaCl}$ solution with EC values of $14 \mathrm{dS} . \mathrm{m}-1$. The flowers sampling was done in two Golshan Anar regions on the springtime based on a completely randomized design with three replications. The development steps of male gametophyte in pistachio plant were observed using conventional cell histology techniques and light microscopy observations and were then contrasted with samples subjected to no salinity stress. The results represented that several steps of male gametophyte development are as follows: (1) the anther experiencing normal growth which is tetrasporangiate, (2) cytokinesis taking place simultaneously with meiosis in the microspore mother cell, the tetrahedral tetrads, (3) microspores being delivered after meiosis by microsporogenesis were more or less irregular in shape during the contraction period. Finally, the abnormal shape and structure of the number of cases reviewed in three replicates of pollens can be one of the significant factors influencing the decline in the product.
\end{abstract}

Keywords: Anther, Pistacia, salinity

\section{INTRODUCTION}

Adversely, salinity influences the growth and development of plant and it is a major environmental stress limiting agricultural production (Saini 1997). Reproductive outgrowth starting from meiosis in the spore mother cells for fertilization and untimely seed formation is highly sensitive to various stresses, such as drought, heat, cold, flooding, and nutrient insufficiencies (Salter and Goode, 1967; O'Toole and Moya, 1981; Saini and Aspinall, 1981, 1982; Westgate and Boyer 1986; Satake and Yoshida 1978; Schoper et al. 1987; Morrison 1993; Hayase et al. 1969; Brooking 1976, Matsushima, 1962; Zavadskaya and Skazkin 1960; Campbell and Leyshon, 1980; Sharma et al. 1987; Azouaou and Souvré 1993; Lardon and TriboiBlondel, 1994). These stresses lead to several structural and functional deformities in reproductive organs, causing failing of fertilization or premature abortion of seed or fruit. Thus, the breakage to fecundity from stress at this phase is notably critical for crops in which the economic outcome is the result of sexual prolificacy, as elevation in water shortage possibly characterizes as the most significant environmental element restricting global crop fecundity (Fischer and Turner, 1978; Boyer, 1982). Among these stresses, salinity is a main question since the past centuries. Around $20 \%$ of land under implantation and nearly $50 \%$ of watered lands in the world are influenced by ion concentration (Zhu 2002). Elevated salinity has two spoiling impacts on plants. The first is the impact induced by the water deficiency as a product of escalating concentration of soil solution and the other is the impact of toxic ions which hinder enzymatic activity in key processes (Zhang and Blumwald, 2001).

Plants utilize various mechanisms to reduce the impacts of these environmental stresses. One of these mechanisms is the imperfect establishment of eggs or pollen that leads to the displacement of the food founts from the reproductive organs into metabolic reactions and leads to stress resistance. The aging of the reproductive organs can also be stimulated or predated by salinity stress. Asch and Wopereis (2001) stated that $45 \%$ of the rice harvest is lessened by salinity stress as an impact of the clusters sterility and the seed weight reduction in formed seeds. Salinity becomes a major cause of defective grain and product and quality reduction in cotton (Davidonis, Johnson, and Landivar, 2000).

The studies of Namuco and O'Toole (1986) and Westgate and Boyer (1986) indicated that during plant growth microspores have elevated sensitivity to salinity. To the mind of Sun et al. (2004), on salinity stress conditions, microsporocytes of Arabidopsis plants did not grow into mature pollens grains but these cells became vacuole and got old in two days. Moreover, the remaining pollen grains stay in the fallen anthers. Prolonged periods of salinity stress gave no effect on mature pollen grains. It verifies that the effect of salinity on the pollen grains relies on the developmental phases of anthers. Male reproductive perfection in plants is exceptionally susceptive to water deficiency during meiosis in the microspore mother cells (Saini 1997). Pistachio (Pistachio vera) a member of the 
family Anacardiaceae and order Sapindales (Al-Saghir, 2010). Morphologically, pistachio (P.vera) is recognized as the oldest species of this genus (Baninasab and Mobli, 2008). $P$. vera is a dioecious woody plant with imparipinnate leaves which fall in autumn (Al-Saghir, 2010).

The male and female anthesis have 450-500 and 150250 flowers, successively. A very long life is owned by this tree whose height can reach 7-10 meters (Asaja, 2006). The surface of the stigma receives pollen when the female flowers are exposed, then pollination takes place that will produce fruit and seeds. The female flower buds located on the branches of a one-year-old tree begin to bloom in late March and 100 to 300 flowers are pollinated in every inflorescence during the first two weeks of April (Polito and Kallsen, 2005). Researchers have conducted many different studies on this species including morphological and developmental studies on female flowers and embryogenesis of the genus Pistacia L (Al-Saghir, 2010; Bachelier and Endress, 2007; Grundwag, 1976) and species P.vera (Lin et al. 1984; Martinez-Palle and Herrero, 1998; Shuraki and Sedgley, 1996; Shuraki and Sedgley, 1997), Endress and Bachelier (2007) have examined the genus Pistacia L. and reported that female flowers have 5-8 excrescences similar to calyx, the female portion holds a large round ovary with short vigor and trifurcation of stigma (two lobes on each branch). Grundwag (1976) stated that this genus has one ovule per ovary, a downwardmoving ovary, a monolayer, and many nuclei. The embryonic sac of the genus (Grundwag, 1976) and species (Lin et al. 1984) have Polygonum-type. Yet, there are various studies on male flowers (Al-Saghir, 2010; Asaja, 2006; Azouaou and Souvré, 1993; Bachelier and Endress, 2007; Shiyan et al. 2001; Li et al. 2011; Qiu et al. 2010). Various researches have been done on the morphological structure, but less attention has been provided to the founding of sapidity in pistachios. Other researchers carried out morphological studies on pistachio pollen and declared that their morphology was diversified among different varieties (Afshari et al. 2008; Davarynejad et al. 1996; Li et al. 2011; Qiu et al. 2010).

Pistachio beans own a special economic significance in the family Anacardiaceae, genus Pistacia L. in accordance with Molecular Data Bank of Iranian Pistachio reported in 2008, pistachio is the first non-oil exported product in Iran (IPMD). Several techniques and studies have been carried out to establish the knowledge about this precious species as well as to determine distinction among diverse varieties. Yet, the morphological and developmental evaluation of flowers, particularly male flowers, are very finite. The essential characteristics of reproductive organs and understanding the developmental phases of gametophytes find a substantial significance in botanical sciences since they are the proper equipment for the recognition and categorization of plants. The hodiernal inquiry arranges to learn anatomical characteristics of male flower and developmental phases of anthers in pistachios and the impact of salinity on these phases in natural circumstance with no entry of any natural and experimental factors. Biological stress of Pistacia was observed by Seydi et al. (2015), Parsa and Karimian (1975), Ranjbar et al. (2002),
Chelli-Chaabouni et al. (2010), and Bastam et al. (2013).

\section{MATERIALS AND METHODS}

This comparative study was carried out on two locals with identical conditions involving control garden (A) which was watered with fresh well water and other garden (B) which was watered with salty water with EC (electric conductivity) value of $14 \mathrm{dS} . \mathrm{m}-1 \mathrm{NaCL}$ solution. Based on a completely randomized design with three replications, a sampling of flowers was taken place in two gardens of Golshan Anar area in the springtime. Golshan is a village located around Anar in the suburb of Rafsanjan city, Kerman Province. The study area is $14 \mathrm{~km}$ southeast of Anar, at $30^{\circ} 48^{\prime} \mathrm{N}$ and $55^{\circ} 21^{\prime} \mathrm{W}$, and the average height of $1408 \mathrm{~m}$ with a desert and hot-dry climate. The sampling of soils was conducted on the surface up to a depth of $120 \mathrm{~cm}$, it was to determine the soil texture, and, by this, the percentage of each of the three particles i.e. sand, silt, and clay were analyzed in the soil laboratory of Rafsanjan's Pistachio Research Center. Then, by the technique of soil textural triangle, the percentage of sand was determined as shown in table 1 (Mohammadi, 2006).

To learn about the developmental phases of anthers, sampling from male inflorescence buds was carried out until the opening of anthers and pollination. Morphology of inflorescence and male flowers was examined using a dissecting microscope. To learn about the anatomy and the development, the samples were soaked in FAA solution $(90 \%$ ethanol $70+5 \%$ acetic acid $+5 \%$ formaldehyde) for 24-72 hours (Johansen, 1940), and then placed in the running water for 24 hours. The samples were dried in ethanol with series of increasing concentrations and then soaked in alcohol $70 \%$. For paraffin embedding, the samples were first dried using ethanol 70, and then the ethanol in tissues was little by little substituted with toluene (paraffin solvent) by soaking the samples in solutions with increasing toluene level for 20 minutes. Next, molding was carried out on samples by putting them in molten paraffin for at least 7 hours. Sectioning was performed using a rotational microtome with a thickness of 0.8 micrometers. The slides were deparaffinized by toluene and blemished with Hematoxylin-Eosin according to the protocol suggested by Meyer (Yeung 1984). To cling the samples, the sections were first dried in distilled water and increasing ethanol series and until they became transparent in toluene. Finally, the permanent slides were acquired using Entalen glue and coverslip. Microscopic examination of samples was performed under a light microscope (Olympus BH2 Japan) and the suitable samples were photographed with a digital camera (Canon IXUS 120 IS USA).

Table 1. Soil particles percentage and type of soil texture

\begin{tabular}{lcccc}
\hline \multirow{2}{*}{$\begin{array}{l}\text { Area of } \\
\text { Pistachio }\end{array}$} & \multirow{3}{*}{ Type of soil texture } & $\begin{array}{c}\text { Clay } \\
(\%)\end{array}$ & $\begin{array}{c}\text { Silt } \\
(\%)\end{array}$ & $\begin{array}{c}\text { Sand } \\
(\%)\end{array}$ \\
\hline A & Sandy loam (light) & 19.8 & 25.6 & 54.6 \\
B & Sandy loam (light) & 19.8 & 17.6 & 62.6
\end{tabular}




\section{RESULTS AND DISCUSSION}

\section{Results}

The study on morphology and anatomy of male flowers indicated that the formation of male inflorescences is in the form of complex and lateral panicle on the branches before the leaves appeared (Figure 1.A). During the flowering period, the color of anthers is red and it later changes during development phases. At the pollination period, they are completely yellow or their pedicel is yellow, but the tip remains red. The color of anthers changes starting from the ventral surface of inflorescence to the dorsal surface (Figure 1.B-C).
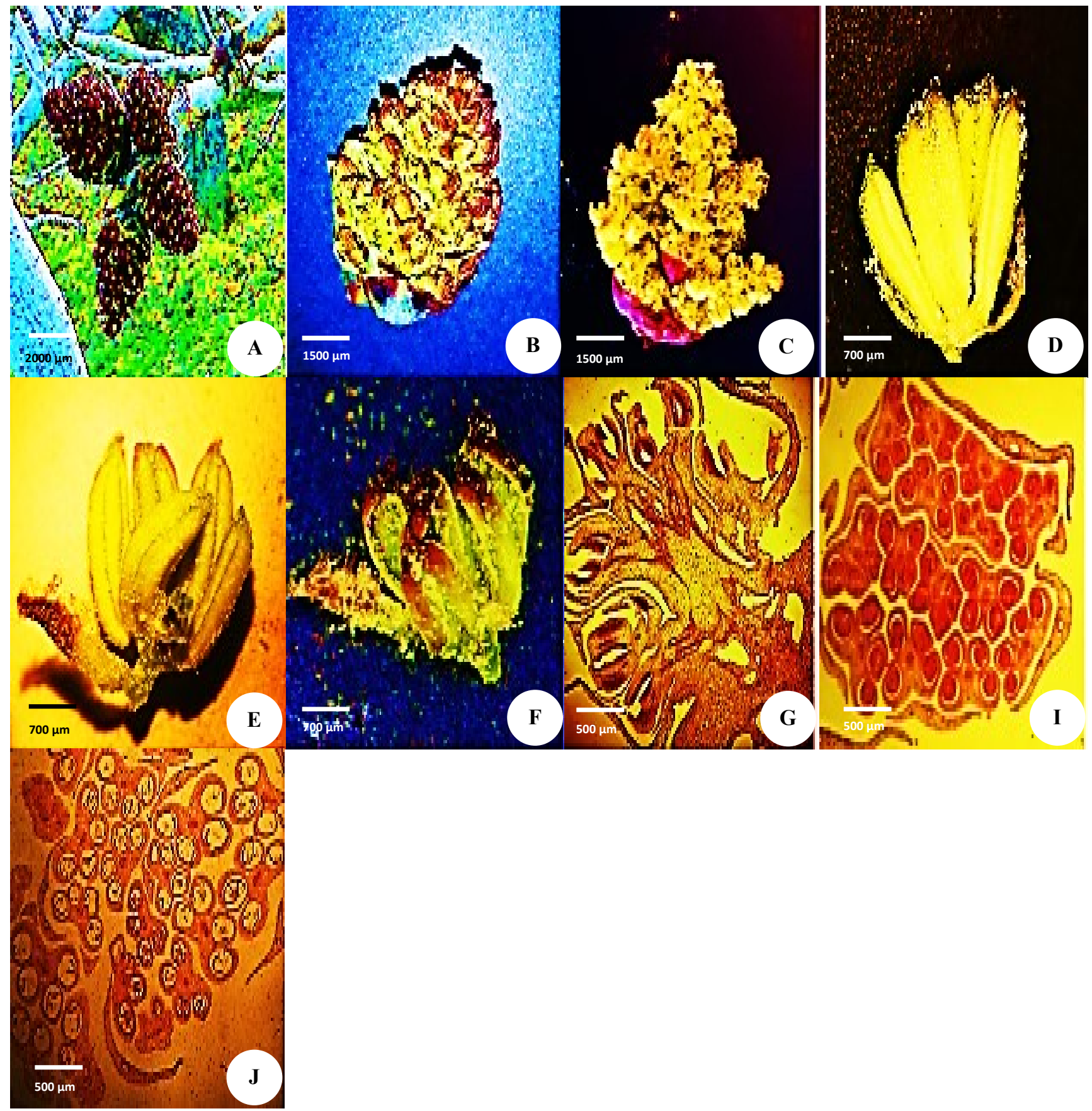

Figure 1.A-I. Morphological and anatomical structure of inflorescence and male pistachio flowers $(P$. vera): A. Emerging male inflorescence laterally before the leaves; B. Dorsal surface of the male inflorescence bridge along with red anthers; C. Surface of male inflorescence showing color changes of anthers to yellow; D-E. Male flower panicles with a short peduncle and large anthers with 2 sepal 1 bract; F. Flower with of dehiscent anther, G. Longitudinal section of inflorescence, the arrow refers to the secretory ducts in the side of vascular bundles; H-I. Cross-section of inflorescence, narrow arrow points flower with five anthers, thick arrow shows flower with four anthers and five anther arrowhead shows flower with six anthers and seven anthers, $A=$ Anther, $\mathrm{S}=\mathrm{Sepal}, \mathrm{B}=\mathrm{Bract}$ 
Four to six stamens with large and bulky anthers are owned by male flowers, plus two or three sepals and $0-1$ bract; the sepals and the bracts are recognizable by the size. Filaments are short and huge. In length and depth close to the central vascular bundle of anthers, the dehiscence of anthers occurs (Figure 1.D-F). The number of anthers per flower was confirmed by cross sections of male inflorescence and it resulted that the four-anther was dominant (Figure 1.H-I). The arrangement of flowers as panicle is confirmed by longitudinal section of inflorescence. In addition, the secretory ducts in the vascular bundles are exposed (Figure 1.G).

Three steps, namely, pre-meiotic, meiosis and postmeiotic involves in the development of anther and they are concluded from the examination of microscopic sections.
From division and differentiation of one or more epidermal anthers cell (s), microsporangium wall and spore-forming tissue are produced. By dividing high colorable cells and dense cytoplasm, spore-forming tissue is detected (Figure 2.A). The distance of two dorsal sporangia is shorter than that of the two ventral sporangia; at this stage, microsporangia located in a theca are far away from each other, and they are also split up from each other by septum in depth. As the spore-forming tissue divisions process occur, tangential divisions of some cells obtained from epidermal cell division take place to form the anthers walls. Pre-meiotic stage is finished by halting mitosis of sporeforming tissue and transformation of spore-forming cells to microspore mother cells that are large cells with bulk nucleus and dense cytoplasm (Figure 2.B).

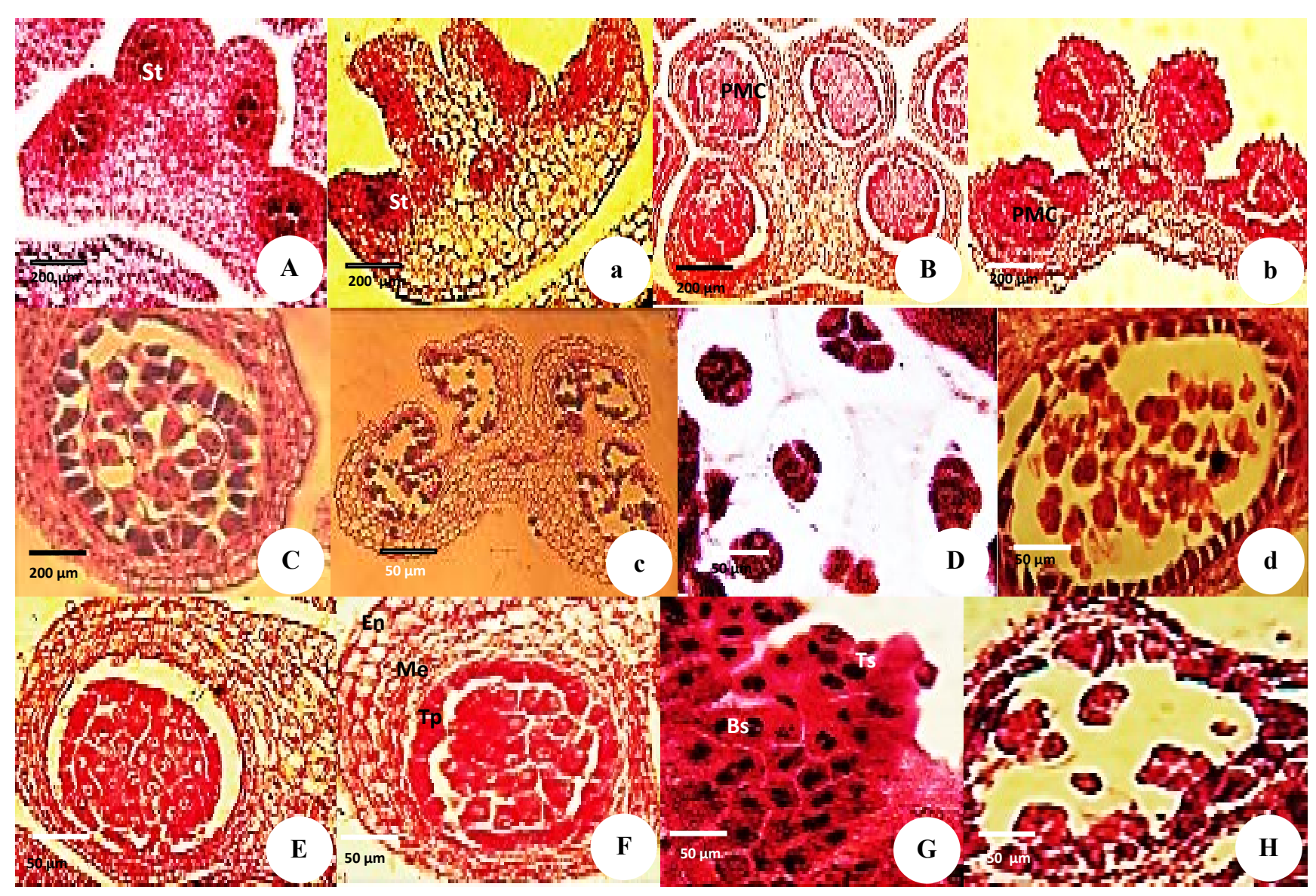

Figure 2. A-H. Stages of forming tetrad microspores inside of anthers in normally grown pistachio (P. vera) and in plants under $\mathrm{NaCl}$ treatment: A. Entire cross-section view of anther at the mitosis division of spore-forming tissue cells phase, in plants under salinity treatment on the right figure anthers were small, shriveled; B. Stopping of mitosis in spore-forming tissue cells and microspore mother cells, in plants under salinity treatment on the right figure anthers were small, shriveled and distancing from nutritional layer; E. Spacing between nutritional layer and microspore mother cells with high magnification; C. On the right figure entire view of anthers with microspores mother cells in meiosis; F. Anther wall of microspore mother cell meiosis time, which is composed of the epidermis, a mechanical layer, more than three middle layers and taptom; G. PMC in two and four-core stage, D\&H. Cytoplasm division simultaneously in the microspore mother cells and production of tetrahedral tetrad surrounded by a thick layer of transparent callus, ST $=$ spore-forming tissue, $\mathrm{PMC}=$ microspore mother cells, $\mathrm{Ts}=$ quad-core microspore mother cells $($ tetrad cell), Bs $=\mathrm{a}$ dual-core microspore mother cells (dyad cell), TP = nutritional layer 


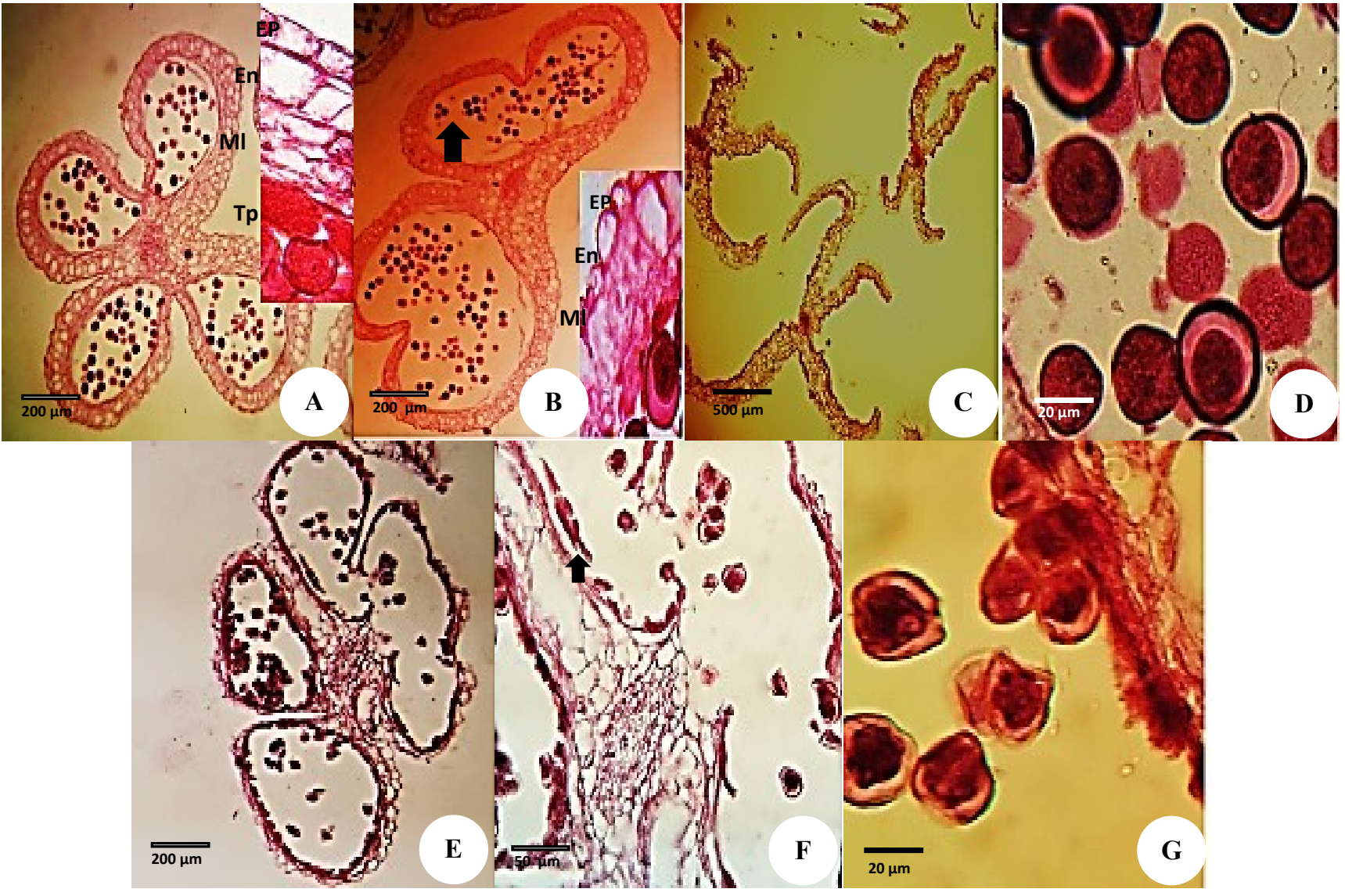

Figure 3. A-D. Anatomical structure of anther cross-sections of normally grown pistachio $(P$. vera), and E-G. in plants under salinity treatment since the production of free microspore to flourish anther: A. Complete decomposition of callus wall surrounding the tetrad and production of free microspores entire. Cross-section view of anther in the mature pollen. Arrowhead points out to the break down of the walls of a cavity for anther dehiscence. Anthers wall is composed of an epidermis layer, a mechanical wall layer, three middle layers and a tapetum layer, and entire view of anther cross-section at free microspores stage and disappearance of nutritional layer; B. Microspores feeding nutrition layer, leading disappearance of nutritional layers with the middle layer cells; C. Entire view of dehiscent anther; D. Mature pollen; E. Entire cross-section view of anther in the mature pollen grains. Arrowhead points out to break down the walls of a cavity for anther dehiscence in plants under salinity treatment, F. Anther with mature pollen Arrowhead points out to break down the walls of a cavity for anther dehiscence in plants under salinity treatment, G. Mature pollen under salinity treatment; EP = epidermis, $\mathrm{En}=$ mechanical layers, $\mathrm{ML}=$ middle layer

To begin the Meiotic stage was by taking away of the microspore mother cells from tapetum cells. At this stage, central indentation of each anther theca is completely deep and reaches to the central vascular bundle near to anther, so that the two microsporangia in the theca are completely separated from each other and the septum is hidden (Figure 2.B). As the phase of meiosis I happen, pectocellulosic wall of microspore mother cells is hydrolyzed and replaced by new callus walls. These walls keep away microspore mother cells from interacting with each other during meiosis. At the time of meiosis phase of microspore mother cell, anther wall is composed of epidermis, a mechanical layer, more than three middle layers and nutritional layer (Figure 2.F). In plants under salinity treatment, although florets appeared usual, but the growth of the anthers was unusual, and more anthers were small and whitered (Figure 2.A-D right). During meiosis of these cells, Cytoplasm cleavage happens at the same time. Inside of each microsporangium at this stage, microspore mother cells with two and four cores are available successively after meiosis I and II (Figure 2.G). After meiosis, the cytoplasm cleavage is performed by the setting up channels of the microspore mother cell in which these cells are oriented as tetrahedral type and are called tetrahedral tetrad. All tetrads are of tetrahedral type and four cells are situated in a common callus wall and also are divided by a callus (Figure 2.H). Post-meiotic phase starts after the splintering of the callus wall and passing from tetrad phase to free microspore phase. At the commencement of this process, microspore is still in tetrad configuration. Microspores hold a certain nucleus with marginal place and congested cytoplasm after being exempted from tetrad at the beginning of discrepancy. Then, the callus lid vanishes entirely and the anther wall possesses mechanical layer, three middle layers and nutritional layer (Figure 3.A). At last,, middle and tapetum layers vanish with the 
discrepancy of fully grown pollen grains; tapetum is glandular (Figure 3.B). Then the impact of condensing of mechanical layer walls become clearly visible, except the epidermis wall that causes to the impression of a U-shaped motif layer (Figure 3.D). Fully grown anther wall owns the mechanical layer with U-shaped motif along with the traces of tapetum layer and the middle layer. The separation of the two middle walls of each sac with the central part of anther causes to dehiscence in length and depth (Figure 3.A-C, E). Anther was shriveled and pollen grains owned unusual form (Figure 3.E-G).

\section{Discussion}

Pistachio is a plant with high economic value and it is native to Iran, as plant in cultivation, it is widely planted in various locations. It is so significant to do research on the bioecological and ecological issues of the plant, including the sorts of stress in Iran, such as the $\mathrm{NaCl}$ stress which is one of the major issues in cities and in the locations for pistachio cultivation. Biological stress of Pistacia was observed by Parsa and Karimian (1975), Ranjbar et al. (2002), Chelli-Chaabouni et al. (2010), Bastam et al. (2013), and Seydi et al. (2015). Al-Saghir (2010) in the study of the genus Pistacia L. informed that the flowers are small, monoecious, with no petal and panicle type of inflorescences. This research also informed that the flowers are monoecious and are born from female pedicel in complex panicle and on separate pedicels, as well as hold 4- 6 stamens, 2 or 3 sepals and the $0-1$ bract. The sum of stamens in the genus Pistacia were 4-6 pcs which has been informed by Hormaza and Polito (1996), 3-5 pcs by Shiyan (2001), and 4-5 pcs in species P. chinensis by Qiu et al. (2010). Al-Saghir (2010) in the research of genus Pistacia L. exerted bracteole term for non-bracteal excrescences surrounding flowers. Male and female flowers of this genus hold 1-3 small bracts and 2-7 bracteoles. Moreover, Bachelier and Endress (2007) familiarized non-bracteal excrescences as sepals and informed its numbers in male flowers of $P$. lenticus are identical with their stamens numbers, which was 4-6. These researchers informed that they feel doubt if these excrescences are sepals or bract, they also informed that 5-10 sepals-like organs in $\mathrm{P}$. terbinthus and only two of them in P. mexicana. In addition, as the flowers of the genus Pistacia are pollinated by wind, it indicates the tendency of evolution route towards being dioecious and losing perianth (petals shortage and diminished sepals). In our review studies, only a few numbers of reports were discovered about growth phases of anther to deliver pollen in the genus pistachios. there was individual study in the $P$. vera species done by Li et al. (2011). In this study, during meiosis, the anther wall of microspore mother cell consists of the epidermis, a mechanical layer with more than three middle layers, and a glandular tapetum layer. The stability feature of middle layers is important in this species. Because in most crops, middle layers vanish at untimely phase and before the establishment of the tapetum layer (Sanders et al. 1999), but in this species, middle layers vanish within tapetum layer at the pollen grains discrepancy, and this is in agreement with Li et al. (2011) who have also notified this characteristic. The cytoplasmic classification was synchronous after meiosis of microspore mother cell, conformable to that of the polygonum type; this finding and glandular tapetum layer are in line with results of $\mathrm{Li}$ et al. (2011) on P. vera and results of Qiu et al. (2010) on P. chinensis. In this research, the researchers examined that cytoplasmic partition after meiosis is carried out synchronously by setting up channels from around microspore mother cell toward the center of cell and building up four microspores. These cells are oriented tetrahedrally. In this study, all tetrads were tetrahedral. Li et al. (2011) discovered that tetrad of $P$. vera is isobilateral, so there are both types of tetrad in varieties of $P$. vera. Qiu et al. (2010) informed that P. chinensis has both types of tetrahedral and isobilateral tetrads. In pre-meiotic phase, parts of microsporangia situated in one theca are secluded from each other via the septum. But in meiotic phase, middle indentation of each theca of anther turns into totally deep until it arrives in the central vascular bundle of anthers, so that the two microsporangia in a theca are totally secluded from each other. This stuff is also found in few plants. In most cases, the septum totally secludes two pollen sacs until the end of the maturation phase. At last, the two sacs are attached and let pollens out via shallow dehiscence pore. The post-meiotic phase starts with disintegration of callus wall and passing tetrad phase to microspore phase. At last, middle stratum and tapetum stratum vanish with distinction of fully-grown pollens. Fully-grown anther wall is equipped with the mechanical stratum with U-shaped motif along with the traces of the tapetum stratum and the middle stratum. Separation of the two middle walls of each sac with the central part of anther leads to dehiscence in length and depth. The pollens are detached across the deep cleavage locations.

Crops manage the establishment of pollen grains, eggs, and grains in reaction to environmental circumstance change. In extreme environmental circumstance, establishment of pollen grains will fail. In this research, the male gametophyte growth phase in pistachio plant was examined with standard methods and plant reaction to $\mathrm{NaCl}$ stress at this phase was observed. The findings yielded from this study is in a mutual accord with the result of prior studies on the preventative effect of salinity stress on male gametophyte growth in plants (Namuco and O'Toole 1986, Moss and Downey 1971, O'Toole and Moya 1981, Saini 1981, Sheoran 1996, Westgate and Boyer 1986). Namuco and O'Toole (1986) revealed that microspores are susceptive to salinity stress during the development phase. In some plants, including beans, canola, corn, and soybeans, stress circumstances lead to the mortality of plant cells in the mature gametophytes (Kokubun 2001, Moss and Downey 1971, Sage and Webster 1990, Young 2004). Consequently, the natural growth of gametophyte, embryos, and pollen in plants can be stopped or thwarted by environmental stresses, but the fiasco in the establishment phases relies on the phase where stress is applied. Male reproductive growth in plants is very susceptive to salinity stress and dehydration in PMC during meiosis. During this stage, the establishment of most of microspores or pollen grains is impeded by the water 
deficiency and it leads to male sterility. A direct impact on reproductive tissues is seemingly not the cause of these injuries but an indirect impact of water deficiency in different organs like leaves is. The mechanism of this reaction may involve a long distance molecular warning in organs that are under pressure and influences fertility in reproductive tissues. A lot of studies notify the complicity of abscisic acid in this matter, but more clue is needed to verify the participation of this hormone in the induction of male sterility (Morgan 1980, McRae 1985).

The discontinuation of male gametophyte growth caused by stress circumstances is as a result of disruption of carbohydrates metabolism and distribution within the anther, and the stoppage of the sugar hydrolysis key enzyme, which is invertase. The glucose level can organize the gene expression of invertase. Salinity stress can cause the decrease in photosynthesis that will lead to the decrease in sugar distribution to the reproductive tissues and this could be a signal of the cause for metabolic changes, resulting in the fiasco of the male gametophyte establishment (Dorion et al.1996, Saini et al. 1984)). The discontinuation of the male gametophyte establishment, that brings about the sterility of pollen grains, is the most typical among cereals. A sharp decline in crop production in many dicotyledonous plants is due to the drought led by the salinity stress during the growth of the stamen to the growth of anthers (Dubetz and Bole 1973; Salter and Goode 1967, Sato 1954, Turner 1993, Wells and Dubetz 1966, Westgate and Peterson 1993).

Saini et al. (1984) and Lalonde et al. (1997) have studied the anomalies in the development phase of anthers exposed to salinity stress and water shortage during meiosis. They pointed out that microspore stem cells apparently finalize the meiosis completely, but the development phase of more microspores is ended in the next steps. The most usual sign of the fiasco of development phase is the transference of microspores from their natural margin location. This can occur at any time among the young microspore step and the first mitosis of the pollen grain, and the period apparently depends on the cultivar. In some of the anthers, unusual vacuolation of tapetal layer after meiosis can be observed. Consequently, the incorrect function of tapetal may guide to incorrect orientation of microspores. Studies of Saini and Aspinal (1981) and Sheoran and Saini (1996) pointed that pollen grains with improper orientation and diluted cytoplasm have sheer antin or without it, but they own exine and compile no starch, that is the primary factor of productivity of the grass pollen grains. The anomalies in matching and dissociation of chromosomes during meiosis in pollen mother cells in the barley under the salinity and drought stress was originally observed by Skazkin and Zavadskaya (1957). These anomalies were identified as the cause of male sterility. Namuco and O'Toole (1986) also denounced that several chromosomal anomalies in rice are escalated under the stress of water shortage. In most cases, the results of this study explicated that the salinity circumstances in the flowering phase lower the quantity of pollen grains in anther. Moreover, anthers development phase is abnormal under salinity circumstance resulting some of anthers are wrinkled, discolored, and small. The untimely cracking of the anther wall, the shrinkage of pollen grains, and the establishment of pollen with unusual shapes and properties verify that the salinity stress lessens the yield of Canola through impacting the male gametophyte development (Mahmoodzadeh and Bemani 2008). Learning separate environmental circumstances in the future and changes that take place during the growth phases of the pistachio and its reproductive organs is nominated. Saini et al. (1984) and Lalonde et al. (1997) examined the anomalies of anthers growth due to salinity stress and water deficit at the time of meiosis

\section{REFERENCES}

Afshari H, Talaei A, Panahi B, Hokmabadi H. 2008. Morphological and quantitative study of pistachio (Pistacia vera L.) pollen grains and effect of different temperatures on pomological traits. Aust J Crope Sci 1 (3): 108-114.

Al-Saghir MG. 2010. Phylogenetic analysis of genus Pistacia L. (Anacardiaceae) based on morphological data, Asian J Plant Sci 9 (1): 28-35.

Asaja C. 2006. The pistachio tree cultivation in "Alternative forms of occupation and continuous educational training in Agriculture" Project Agreement n ${ }^{\circ} 2004$ EL/04/B/F/PP-148258.

Asch F, Wopereis MCS. 2001. Responses of field-grown irrigated rice cultivars to varying levels of floodwater salinity in a semi-arid environment. Field Crops Res 70: 127-137.

Azouaou Z, Souvré A. 1993 Effects of copper deficiency on pollen fertility and nucleic acids in the durum wheat anther. Sex Plant Reprod 6: 199-204

Bachelier JB, Endress PK. 2007. Development of inflorescences, cupules, and flowers in Amphipterygium and comparison with Pistacia (Anacardiaceae). Intl J Plant Sci 168 (9): 1237-1253.

Baninasab B, Mobli M. 2008. Morphological attributes of root systems and seedling growth in three species of Pistacia. Silva Lusitana 16: $175-181$.

Bastam N, Baninasab B, Ghobadi C. 2013. Improving salt tolerance by exogenous application of salicylic acid in seedlings of pistachio. Plant Growth Regul 69: 275-284

Boyer JS. 1982 Plant productivity and environment. Science 218: 443-448

Brooking IR. 1976 Male sterility in Sorghum bicolor L. Moench induced by low night temperature. I. Timing of the stage of sensitivity. Aust J Plant Physiol 3: 589-596.

Camello-Guerreiro SM, Paoli AAS. 2005. Anatomy of pericarp and seedcoat of Lithraea molleoidea (Vell.) Engl. (Anacardiaceae) with taxonomic notes, Brazilian Archives of Biology and Technology, 48: 599-610.

Campbell CA, Leyshon AJ. 1980 Effect of nitrogen supply on the seed set of spring wheat and barley. Can J Plant Sci 60: 785-794

Chelli-Chaabouni A, Ben Mosbah A, Maalej M, Gargouri K.GargouriBouzid R, Drira N. 2010. In vitro salinity tolerance of two pistachio rootstocks: Pistacia vera L. and P. atlantica Desf. Environ Exp Bot 69: 302-331.

Davarynejad G. H, Rashed M. H, Vatanpoor A, Csillag F. 1996. The morphology of pollen grains as an indicator for identification of male pistachio (Pistacia vera L.) trees. ISHS Acta Horticulture 419: I International Symposium on Pistachio.

Davidonis GH, Johnson A, Landivar JA 2000 Cotton mote frequency under rainfedand irrigated condition. J Cotton Sci 4: 1-9.

Dorion S, Lalonde S, Saini HS1996. Induction of male sterility in wheat by meiotic -stage water deficit is preceded by a decline in invertase activity and changes in carbohydrates metabolism in anthers. Plant Physiol 111: 137-145.

Dubetz S, Bole JB. 1973Effect of moisture stress at early heading and of nitrogen fertilizer on three spring wheat cultivars.Can J Plant Sci 53: $1-5$

Fan M, Zhu J, Richard C, Brown KM, Lynch JP. 2003. Physiological roles for aerenchyma in phosphorus-stressed root, Func Plant Biol 30: 493-506. 
Ferguson L, Polito V. S, Kallsen C. 2005. The pistachio tree; botany and physiology and factors that affect yield, California PistachioManual, 31-40.

Fischer RA, Turner NC. 1978. Plant productivity in the arid and semi-arid zone. Annu Rev Plant Physiol 29: 277-317

Grundwag M. 1976. Embryology and fruit development in four Pistacia L. (Anacardiaceae), Bot J Linn Soc 73: 355-370.

Hayase H, Satake T, Nashiyama I, Ito N. 1969. Male sterility caused by cooling treatment at the meiotic stage in rice plants.II. The most sensitive stage to cooling and fertilizing ability of pistils. Proc Crop Sci Soc Jpn 38: 706-711

Hormaza J. I, Polito V. S. 1996. Pistillate and staminate flower development in dioecious Pistacia vera (Anacardiaceae), Amer J Bot 83 (6): 759-766.

Johansen DA. 1940. Plant Microtechnique. McGraw-Hill, New York.

Kokubun M, Shimada S, Takahashi M 2001 Flower abortion caused by preanthesis water deficit is not attributed to impairment of pollen in soybean. Crop Sci 41: 1517-1521

Lalonde S, Beebe D, Saini HS. 1997. Early signs of disruption of wheat anther development associated with the induction of male sterility by meiotic -stage water deficit. Sex Plant Reprod 10: 40-48.

Lardon A, Triboi-Blondel AM. 1994. Freezing injury to ovules, pollen and seeds in winter rape. J Exp Bot 45: 1177-1181

Li XX, Bai ZY, Lu BS, Pang M, Wang J, Feng XB, Dong Q. 2011. Megasporogenesis, microsporogenesis and development of gametophytes of Pistacia vera, Acta Horticulture Sinica 38 (8): 1447 1454.

Lin T. S, Crane J. C, Polito V. S. 1984. Anatomical aspect of abscission in pistachio. J Am Soc Hortic Sci 109: 69-73.

Mahmoodzadeh H, Bemani M. 2008. Influence of Salinity at Early Stage of Flowering on the Development of Male Gametophyte in Canola (Brassica napus L.) cv. Symbol Res J Environ Sci 2: 415-423.

Martinez-Palle M, Herrero M. 1998. Pollen tube pathway in chalazogamous Pistacia vera L. Int J. Plant Sci 159 (4): 566-574.

Matsushima S. 1962. some experiments on soil-water-plant relationship in the cultivation of rice. Proc Crop Sci Soc Jpn 31: 115-121.

McRae DH. 1985 Advances in chemical hybridization.Plant Breed Rev 3 : 169-191.

Morgan JM. 1980 possible role of abscisic acid in reducing seed set in water-stressed wheat plants. Nature 289: 655-657.

Morrison MJ. 1993. Heat stress during reproduction in summer rape. Can J Bot 71: 303-308.

Moss GI, Downey LA. 1971. Influence of drought stress on female gametophyte development in corn (Zea mays) and subsequent grain. Crop Sci 11 (3): 368-372.

Namuco OS, O'Toole JC. 1986. Reproductive stage water-stress and sterility.1.effect of stress during meiosis. Crop Sci 26: 317-321.

O'Toole JC, Moya TB. 1981 Water deficit and yield on upland rice. Field Crop Res 4: 247-259.

Parsa A.A, Karimian N. 1975. Effect of sodium chloride on seedling growth of two major varieties of Iranian pistachio (P. vera L.). J Hort Sci 50: 41-46.

Qiu ZF, Li BG, Gu YH, Li YC, Zhang YQ, Qi K. 2010. Megasporogenesis, microsporogenesis and development of female and male gametophyte of Pistacia chinensis bunge. Acta Botanica Boreali-Occidentalia Sinica 2010 (7): 1359-1365.

Ranjbar A, Van-Damme P, Samson R, Lemeur R. 2002. Leafwater status and photosynthetic gas exchange of Pistacia khinjuk and $P$. mutica exposed to osmotic drought stress. Acta Hort 591: 423-428.

Sage TL, Webster BD. 1990. Seed abortion in Phaseolus vulgaris L. Bot Gaz 151: 167-175.

Saini HS, Aspinall D. 1981 Effect of water deficit on sporogenesis in wheat (Triticum aestivum L.). Ann Bot 48: 623-633
Saini HS, Aspinall D. 1982. Abnormal sporogenesis in wheat (Triticum aestivum L.) induced by short periods of high temperature. Ann Bot 49: $835-846$

Saini HS, Sedgley M, Aspinall D. 1984. Developmental anatomy in wheat of male sterility induced by heat stress, water deficit or abscisic acid.Aust J Plant Physiol 11: 243-253.

Saini HS. 1997. Effects of water stress on male gametophyte development in plants. Sex Plant Reprod 10: 67-73.

Salter PJ, Goode JE. 1967. Crop responses to water at different stages of growth (Research review number 2) Commonwealth Agricultural Bureaux, Farnham Royal, UK

Sanders P, Bui A, Weterings K, Mclntir K.N, Hsu Y, Lee P, Truong M, Beals TP, Goldberg RB. 1999. Anther developmental defects in Arabidopsis thaliana male sterile mutants. Sexual Plant Reprod 6: 297-322.

Satake T, Yoshida S. 1978. High temperature-induced sterility in indica rice at flowering. Jpn J Crop Sci 47: 6-17

Sato K. 1954. Relationship between rice crop and water. Jpn J Breed 4: 264-289

Schoper JB, Lambert RJ, Vasilas BL, Westgate ME. 1987. Plant factors controlling seed set in maize. The influence of silk, pollen, and earleaf water status and tassel heat treatment at pollination. Plant Physiol 83: $121-125$

Sharma PN, Chatterjee C, Sharma CP, Agarwala SC. 1987. Zinc deficiency and anther development in maize. Plant Cell Physiol 28: 11-18

Sheoran IS, Saini HS. 1996. Drought-induced male sterility in rice: changes in carbohydrate levels and enzyme activities associated with the inhibition of starch accumulation in pollen.Sex Plant Reprod 9: 161-169.

Shiyan X, Jain L, Mijiti A. 2001. A review on reproducing biology on Pistacia vera L. Acta Horticulturae Sinica.

Shuraki Y D, Sedgley M. 1997. Pollen tube pathway and stimulation of embryo sac development in Pistacia vera (Anacardiaceae), Ann. Bot 79: 36369.

Shuraki Y. D, Sedgley M. 1996. Fruit development of Pistacia vera (Anacardiaceae) in relation to embryo abortion and abnormalities at maturity, Austr J Bot 44 (1): 35-45.

Sun K, Hunt K, Hauser BA. 2004. Ovule abortion in Arabidopsis triggered by stress. Plant Physiol 135 (4): 2358-2367.

Turner LB. 1993. The effect of water-stress on floral characters, pollination and seed set in white clover (Trifolium repens L.). Exp Bot 44: 1155-1160.

Wells SA, Dubetz S. 1966. Reaction of barley varieties to soil water stress. Can J Plant Sci 46: 507-512.

Westgate ME, Boyer JS. 1986. Reproduction at low silk and pollen water potentials in maize. Crop Sci 26: 951-956.

Westgate ME, Peterson CM. 1993. Flower and pod development in waterdeficient soybeans (Glycine max L. Merr.). J Exp Bot 44: 109-117.

Yeung EC. 1984. Histochemical and Histochemical staining procedures. In: Cell culture and Somatic Cell Genetics of Plants. Vasil IK. (ed.). Academic Press, Orlando, FL.

Young LW, Wilen RW, Bonham-Smith PC. 2004. High-temperature stress of Brassica napus during flowering reduces micro and megagametophyte fertility induces fruit abortion and disrupts seed production. J Exp Bot 55: 458-495.

Zavadskaya IG, Skazkin FD. 1960. On microsporogenesis in barley as affected by soil moisture deficiency and by application of nitrogen at various stages of development. Dokl Akad Nauk SSSR 131: 692-694.

Zhang HX, Blumwald E. 2001. Transgenic salt-tolerant tomato plants accumulate salt in foliage but not in fruit. Nat Biotechnol 19: 765768.

Zhu JK. 2002. Plant salt tolerance.Trends Plant Sci 6: 66-71. 